\title{
Research on Development of Traditional Arts and Crafts Based on Tourism Perspective
}

\author{
Yi Qiang \\ Beijing Union University, Beijing, China, 100148 \\ yiqiang@163.com
}

Keywords: arts and crafts, tourism industry, tourism development.

\begin{abstract}
The phenomenon of using the traditional arts and crafts to develop the tourism industry is becoming more and more popular, which is conducive to the protection and heritage of the traditional arts and craftsa certain extent. Aiming at the existing problems in the development of the traditional arts and crafts in tourism industry, such as the low development awareness, the single development approach and the poor development quality, this paper puts forward the corresponding suggestions of strengthening the awareness, enriching the means and improving the quality of the development to provide some references for the relevantresearchers.
\end{abstract}

\section{Introduction}

The traditional arts and craftsare the embodiment of the superb skills of the working people and also are the precious cultural wealth of our country. Nowadays, traditional arts and crafts are gradually replaced by industrial products. Many traditional arts and crafts are fading, and even die out: the protection of the heritage of traditional arts and crafts is an unavoidable problem. Tourism development brings an opportunity, however, in the existing tourism development, the development of the traditional arts and crafts, there are many problems. This paper mainly explores the development strategy of the traditional arts and crafts based on tourism in order to enhance the value of the traditional arts and crafts in the tourism industry.

\section{Promotion Effects of Traditional Arts and Crafts to Tourism Industry}

Arts and crafts as a kind of art have a long historyin China. The far ancient jewelry, the Neolithic ceramic, the Xia Shang Dynasty bronzes, the lacquerwares of Qin and Han Dynasties, the porcelain of the Sui and Tang Dynasties and the Furniture of Ming and Qing Dynastiesconstitute the subject of ancient Chinese arts and crafts, but also reflected the Chinese art of the level and the achievement of. Chinese ancient art and art belong to the category of art, and painting, sculpture, architecture together constitute the whole frame of our country art. Arts and crafts as a branch of art, and its categories, we summed up can be divided into ceramics, jade, bronze, lacquer ware, embroidery, furniture etc.These main types are representative of Arts and crafts, it should be said that in different historical periods, both in the practical level or in the aesthetic level are important for people's life. Heritage and protection of the traditional arts and crafts can not only be used as a "historical relics" kept in the museum. To keep pace with the times and to find new opportunities for development are more important. Among them, the docking tourism industry is a kind of effective way, the tourism industry is comprehensive, can use natural, social and other factors for the tourism development services; tourism activities can be integrated into various industries, forming a new type of tourism industry, for example, agricultural tourism, industrial tourism, cultural tourism, etc.. Tourism is a new market and business opportunities for the traditional arts and crafts, the traditional arts and crafts as the local tourism resources are widely used. The traditional arts and crafts products into tourist souvenirs, tourist attractions, most of the arts and crafts tourism souvenirs, a number of scenic spots also built a special tourism products, tourism, etc. The processing of traditional arts and crafts production process was developed into a tourist attractions display scenes or special experience in the project, for example, in the scenic area in the construction of brewing, dyeing workshops. Some well-known traditional arts and crafts production 
was developed for tourism of folk culture village. Food is the local characteristic of the traditional art and fine arts. Because of the development of the tourism industry, some of the traditional arts and crafts have been excavated, sorted out, protected and utilized. Some of the traditional arts and crafts, which are facing decline or even disappear, recovery. The traditional arts and crafts are rich in the type of art, which is involved in all aspects of life, and can provide a variety of tourism resources for the tourism industry. The cooperation and development of the tourism industry and arts and crafts has broad prospects.

\section{Problems of Development of Traditional Arts and Crafts in Tourism Industry}

\section{Low Development Consciousness}

Although modern ideas affect people's life style and consumption concept, people still have a nostalgic complex in the traditional life and art, which makes the traditional art and art features of the process of art still subject to some attention. Although tourism development is one of the effective methods to protect and inherit the traditional arts and crafts, but there are deviations in the actual operation process. Tourism is the economic benefits of the tourism industry, tourism development is the starting point of the traditional arts and crafts as a factor to attract tourists and the conditions for the development of traditional arts and crafts are concerned.This is a positive effect. However, there are traditional arts and crafts are inefficient development, the phenomenon of excessive commercialization, the negative effects of tourism development, which is not appropriate for the use of traditional arts and crafts, instead of the true meaning of traditional arts and crafts, and not heritage. In modern life, some of the traditional arts and crafts culture products (such as classical furniture, etc.) by a small number of consumers, but if only to meet the needs of minority groups, do not pay attention to the cultural and creative ideas, and not focus on creative ideas will have the traditional cultural elements of the product and modern life style and ideas. However, if we cannot actively explore the market to win more consumer groups, it will lead to the lack of long-term vitality of traditional culture.

\section{Single Development Approach}

The development of arts and crafts has a problem of the diversified development in tourism industry. Traditional arts and crafts are introduced to the tourism shopping, recreation, scenic, catering, festivals. Many aspects of development have been richer. But most places cannot be so integrated development.The simplest, direct and provincial strength of the practice is generally the traditional arts and crafts for tourism commodity production. The problem is: first, the use of traditional art and art is not enough, not to achieve a diversified utilization of the tourism industry chain; second, the depth of the application of the traditional arts and crafts is not enough, the simple use of the traditional process of art, not from the formal content of cultural connotation of deep refining. For an example, in the Netherlands, the sabot is traditional arts and crafts products, this but not a classic tourist commodities, and wooden windmill like, on behalf of the culture of the Netherlands. After the founding of the people's Republic of China especially the popularization of modern industrial products, many folk arts and crafts are not very good inheritance, some of the traditional crafts and even lost, in recent years with attached great importance to have a part of the process for product current situation of the inheritance of intangible cultural heritage. But, most of the arts and crafts products don't have the good protection and various implementations.

\section{Poor Development Quality}

The development of traditional arts and crafts in tourism industry also has the quality problem. At present, the blossom everywhere situation of the tourism development of traditional arts and crafts show is stressed to development and utilization of traditional arts and crafts; in fact, the lack of a true value and feasible countermeasures. There are few places to make the traditional arts and crafts to create a tourism brand, the local tourism planning and tourism development strategy is also not the traditional arts and crafts as a special one. There are many problems in the tourism products derived from the traditional arts and crafts. Tourism development of the traditional arts and crafts, the lack of quality awareness in most places. For example, arts and tourism souvenirs in a rough way, similar and single, the lack of creativity has become the ills of tourism; traditional arts and 
crafts scenes experience freely to build, but tourism scenic optional accessories. Existing development is still extensive use, the reason is that the value of the two point one is the value of tourism resources are more abundant, developers are more willing to put the material resources, financial resources into other such as landscape, historical sites and other tourism resources, hoping to see the economic return as soon as possible.Although the government has the development of traditional arts and crafts awareness, few consider it as core elements of local culture.

\section{Development Suggestions of Traditional Arts and Crafts Based on Tourism Perspective}

\section{Cultivate Development Consciousness}

We should promote the transformation of traditional arts and crafts from the auxiliary tourism resources to the core tourism resources and cultivate the government and the masses development consciousness. Traditional culture and geographical features will become more and more valuable, and should be protected and excavated, to recognize the traditional process of the tourism potential, to give attention and policy support. We can keep the traditional craft art, and can make good use of the place.It will help to form the difference on the tourism products, realize the tourism culture. To further excavate the folk handicraft industry to establish a typical character of folk arts and crafts, most of them in the east and the west of Hainan's economic less developed, if not promptly mining may there will be the danger of extinction, to increase research efforts of Hainan Folk Arts and crafts in the status to better organize themselves into a certain influence, the Hainan hand woven, $\mathrm{Li}$ brocade manufacturing, civil production labor tool. In the traditional process of making pottery, it is to give support. Folk arts and crafts master in the hands of the folk art, heritage for hundreds of years or even longer, it's worth a huge potential for the implementation of specific work in the cultural sector, the establishment of project support, but also the government or private educational institutions to cooperate with the government to give macro guidance, private research institutions to complete the excavation work and art research. For example, there are a lot of folk artistsin Jingdezhen's porcelain making process. The government can cultivate young persons to study the technology to develop the local tourism industry.

\section{Enrich Development Approaches}

We should also strive to enrich the development mode according to the single development approaches. It is not limited to the traditional process of the original form of art, through creativity and innovation, through refining and abstraction, to achieve the traditional process of art by the material production value to the cultural and artistic value of the change. Promote the traditional arts and crafts from the field, the traditional use of the cross field, upgrading the use of transformation. It should be from the cultural value of the abstract and embedded in the search for creativity and innovation. Some scholars have suggested that the establishment of the traditional process of art gene pool, to provide the concept of modern design, this traditional process art to the cultural and creative conversion will provide the tourism industry to provide a variety of materials, such as image, meaning, image, symbol, text, etc. Traditional arts and crafts through innovative use, can be re incorporated into the six elements of tourism system, for example, after the abstract of the traditional arts and crafts symbols can be used for tourist attractions and decoration. The combination of the traditional arts and crafts and cultural and creative industries also have great potential, such as derived from the print, film and television works, exhibitions, etc.. Cite an example, Taiwan a number of creative personnel will be the essence of "veterans' village culture" refining, rehearsal of the drama "treasure island" of a village, strongly shook the mind of the audience. Traditional arts and crafts have many manifestations.

\section{Improve Development Quality}

Nowadays, machinery, pipeline products accounts for most of the products. The pure handmade, traditional process in many areas is on behalf of the classic and quality. For example, Switzerland's pure hand watch highly respected, Ferrari car launched a pure hand to create a limited edition". In history, China's many traditional craft art product is shoot products, such as porcelain. However, spread has a lot of traditional arts and crafts in contemporary did not achieve quality development. Lijiang in Yunnan is the country's most famous tourist destination. There are many types of tourist 
souvenirs in the local product categories more, obvious local characteristics. Been here the tourists can often brought back many distinctive tourist souvenirs, so many of the original craftsmen and artists get a good economic benefits, but later because of Lijiang's visibility in the country has greatly improved, many tourists come in droves, many tourists not to higher aesthetic point of view judge the value of the original arts and crafts products. At this time, the volume of industrial products produced a large number of the entire market, affecting the supply of original art and art products. The whole Lijiang tourist souvenirs market product type and quality of rapid decline, make people to the evaluation of the quality of tourism in Lijiang has greatly declined, the impact of the core characteristics of Lijiang tourism, the impact of the tourism economy in Lijiang. In the tourism industry, the traditional arts and crafts are more in the decoration, decoration of the main attractions of the main tourist attractions, cannot guide visitors from the traditional culture of the charm. This phenomenon must be changed. To develop arts and crafts of good quality is necessary to promote the development of traditional arts and crafts based on tourism perspective.

\section{Conclusion}

The tourism industry is a way to protect and inherit the traditional arts and crafts. Through the development of tourism, traditional arts and crafts will be transformed and developed. Traditional arts and crafts are important tourism resources, which are helpful to increase the cultural connotation and characteristics of tourism products. We should cultivate development consciousness, enrich development approaches and improve development quality of the traditional arts and crafts to make them the representative of local culture.

\section{References}

[1] Li Han, Li Yuanjun, A Strategic Study on the Development of Jiangsu Traditional Fine Arts and Crafts CulturalIndustry, J., JournalofJiangsuUniversity (SocialScienceEdition), 6(2010)85-88.

[2] Song Jiayin, The New Exploration of Wuxi Tourist Souvenirs Design and Development—on the Inheritance and Innovation of Traditional Arts and Crafts, D., Jiangnan University, 2014.

[3] Feng Xiao, The Development and Countermeasures of Zhoushan City Tourism Crafts Industry, J., China Science and Technology Information, 24(2012)160-161. 